Rev. Fac. Agron. (LUZ). 2021, 38: 60-83. Enero-Marzo.

DOI: https://doi.org/10.47280/RevFacAgron(LUZ).v38.n1.04

ISSN 2477-9407

\title{
Selección de plantas élites de lechosa 'Maradol' para la producción de semillas de calidad
}

\author{
Selection of elite "Maradol" papaya plants for the \\ production of quality seeds
}

\section{Seleção de plantas elites de mamão 'Maradol' para a produção de sementes de qualidade}

\author{
Ariadne Vegas García*, Andy Díaz, Delis Pérez, Yanet \\ Sandrea ${ }^{\dagger}$, Grigna Piña y Carlos Marín Rodríguez
}

Centro Nacional de Investigaciones Agropecuarias. Instituto Nacional de Investigaciones Agrícolas. (INIA-CENIAP). Maracay, Aragua. Venezuela. Correos electrónicos: (AV) vegaslux@yahoo.com,(iD; (AD) diazaa35@gmail. com,(D; (DP) delispe@gmail.com, (iD; (GP) gpdumo1@gmail.com, (iD; (CP) (CM) carlmarin@gmail.com, (iD.

\section{Resumen}

El cultivar Maradol Roja, originario de Cuba, presenta características morfológicas y agronómicas superiores a los cultivares locales y se ha adaptado a las condiciones edafoclimáticas de Venezuela; razones por las cuales se siembra en mayor proporción y ha sido aceptado ampliamente por los agricultores, comerciantes y consumidores. Sin embargo, la falta de disponibilidad y el alto costo de las semillas importadas limitan su expansión en el país. El objetivo del trabajo fue la selección de plantas andromonoicas del cultivar, procedentes de diferentes fuentes y localidades, basada en las características morfológicas y agronómicas, así como la producción de semillas de buena calidad mediante autopolinizaciones. Las características para la selección se basaron en aquellas propias del cultivar, tales como: inicio de floración entre los tres y cuatro meses del trasplante a campo, altura de floración, menor o igual de $80 \mathrm{~cm}$, inicio de fructificación antes de los 4 meses, altura de las plantas menor a los $2 \mathrm{~m}$, entre otras. Las plantas seleccionadas presentaron bajo porcentaje de esterilidad, de 30 y 64 frutos.planta $^{-1}$, pesos de frutos entre 1,4 a $1,7 \mathrm{~kg}$ y rendimientos estimados entre 42,5 y $98,50 \mathrm{~kg}$.planta ${ }^{-1}$. En cuanto a la calidad del fruto, fueron alargados y lisos, con pulpa gruesa y de color naranja-rojiza. Estas poblaciones se consideran

Recibido el 28-02-2020 • Aceptado el 09-06-2020.

*Autor de correspondencia. Correo electrónico: vegaslux@yahoo.com 
Rev. Fac. Agron. (LUZ). 2021, 38: 60-83. Enero-Marzo.

Vegas et al.

ISSN 2477-9407

la base para la producción de semillas de buena calidad, para continuar el proceso de selección de líneas puras e híbridos más productivos.

Palabras clave: autopolinizaciones, Carica papaya, líneas, mejoramiento genético.

\section{Abstract}

The cultivar Red Maradol native of Cuba, has morphological and agronomic features superior to local cultivars and adapted to soils and climates of Venezuela; that is why it is grown in a greater proportion and has been widely accepted by farmers, traders and consumers. However, the lack of availability and high cost of imported seeds limit its expansion in the country. The aim of this work was to select andromonoecious plants from different sources and locations, based on morphological and agronomic characteristics, and produce good quality seeds by self-pollinations. The characteristics for selection were based on those of the cultivar, such as: beginning of flowering between 3 and 4 months after transplant to the field, height of flowering less than or equal to $80 \mathrm{~cm}$, beginning of fruiting before 4 months, height of plants less than $2 \mathrm{~m}$, among others features. Selected plants showed low percentage of sterility, 30 and 64 fruits.plant $^{-1}$, fruit weights between 1.4 to $1.7 \mathrm{~kg}$, and estimated yields between 42.5 and $98.50 \mathrm{~kg}$.plant ${ }^{-1}$ yields. Regarding fruit quality, they were elongated and smooth, wide orange-red color pulp. These populations are considered the basis for the production of good quality seeds, to continue the process of selection of more productive pure lines and hybrids.

Key words: autopolinations, Carica papaya, lines, plant breeding.

\section{Resumo}

A cultivar Maradol Roja, originária de Cuba, apresenta características morfológicas e agronômicas superiores às cultivares locais e se adaptou às condições edafoclimáticas da Venezuela; Razões pelas quais é semeada em maior proporção e tem sido amplamente aceita por agricultores, comerciantes e consumidores. No entanto, a falta de disponibilidade e o alto custo das sementes importadas limitam sua expansão no país. O objetivo do trabalho foi a seleção de plantas andromonômicas da cultivar, provenientes de diferentes fontes e localidades, com base nas características morfológicas e agronômicas, bem como a produção de sementes de boa qualidade por meio da autopolinização. As características para a seleção foram baseadas naquelas típicas da cultivar, como: início da floração entre três e quatro meses após o transplante no campo, altura da floração menor ou igual a $80 \mathrm{~cm}$, início da frutificação antes dos 4 meses, altura da planta inferior a $2 \mathrm{~m}$, entre outros. As plantas selecionadas apresentaram baixo percentual de esterilidade, de 30 e 64 frutos.planta $^{-1}$, peso de frutos entre 1,4 e $1,7 \mathrm{~kg}$ e produtividade estimada entre 42,5 e 98,50 kg.planta-1 ${ }^{-1}$ Em relação 
Rev. Fac. Agron. (LUZ). 2021, 38: 60-83. Enero-Marzo.

Vegas et al.

ISSN 2477-9407

à qualidade dos frutos, eles eram alongados e macios, com polpa espessa e cor laranja-avermelhada. Essas populações são consideradas a base para a produção de sementes de boa qualidade, para dar continuidade ao processo de seleção de linhas puras e híbridos mais produtivos.

Palavras-chave: autopolinizações, Carica papaya, linhagens, melhoramento genético.

\section{Introducción}

El cultivar Maradol Roja originario de Cuba presenta características morfológicas y agronómicas superiores y estables, entre ellas: plantas precoces de porte mediano, abundante follaje, entrenudos cortos, altura de floración y fructificación baja, flores hermafroditas tipo IV (66\%), femeninas tipo I (33\%), pentandrias e intermedias (tipos II y III, inferior al 1 $\%)$, y flores masculinas prácticamente ausentes. El rendimiento potencial es de 300 t.ha $^{-1}$ en 20 a 22 meses, los frutos son de tamaño y peso mediano (entre 1,6 y 2,2 kg), con un color de pulpa rojo salmón, sobre los $12^{\circ} \mathrm{Brix}$ y de alta firmeza durante la cosecha y postcosecha, permitiendo larga vida de anaquel. Se adapta a condiciones tropicales y subtropicales (Ramos y Ramos, 2002). La alta plasticidad fenotípica de la planta de lechosa le permite adaptarse a muy diversas condiciones agroecológicas (Kaluran et al., 2018).

Entre las desventajas del cultivar se citan la susceptibilidad al virus de la mancha anillada de la lechosa (PRSV, Papaya Ringspot virus, por sus siglas en inglés) y a la bacteriosis causada por Erwinia sp. (Hernández et al., 2019; Maselli et al., 2010; Rodríguez et al., 2013). El propósito

\section{Introduction}

The cultivar Red Maradol, native of Cuba, presents superiors and stables morphological and agronomic features, among them: Precocious plants of medium size, abundant foliage, short internodes, low flowering and fruiting height, hermaphrodite flowers type IV (66\%), female type I (33\%), pentandries and intermediate (types II and III, less than $1 \%$ ), and practically absent male flowers. The potential yield is 300 t.ha $^{-1}$ in 20 to 22 months, the fruits are medium in size and weight (between 1.6 and $2.2 \mathrm{~kg}$ ), with a salmon red pulp color, above $12{ }^{\circ}$ Brix and high firmness during harvest and post-harvest, allowing long shelf life. It adapts to tropical and subtropical conditions (Ramos and Ramos, 2002). The high phenotypic plasticity of the papaya plant allows it to adapt to very diverse agro-ecological conditions (Kaluran et al., 2018).

Among the disadvantages of the cultivar there are susceptibility to the ringspot virus of papaya (PRSV, Papaya Ringspot Virus) and bacteriosis caused by Erwinia sp. (Hernández et al., 2019; Maselli et al., 2010; Rodríguez et al., 2013). The main purpose of plant breeding of papaya throughout the world has been to provide stable production by conferring resistance 
principal de la mejora genética de lechosa en todo el mundo ha sido proporcionar una producción estable al conferir resistencia al PRSV, una enfermedad devastadora que se transmite por los áfidos (Ogata, et al., 2016). Sin embargo, los esfuerzos de mejoramiento convencional para desarrollar resistencia a PRSV no han sido totalmente exitosos (Rimberia, et al., 2018). En México se ha observado que los cultivares Maradol y Red Lady pueden compensar la pérdida de producción debida a los efectos del PRSV por sus altos rendimientos; sin embargo, el rendimiento potencial puede variar según las regiones y técnicas de manejo empleadas (Rivas et al., 2003).

En Venezuela, la lechosa se cultiva en todo el territorio, en huertos caseros y en unidades de producción pequeñas y medianas (entre 1,5 y 5 ha). Comercialmente, para el año 2015 se sembraron unas 11.200 ha, con una producción de 203.000 t (FEDEAGRO, 2019). Las plantas presentan porte alto; floración tardía a $1 \mathrm{~m}$ de altura, aproximadamente y alta fructificación; cierto porcentaje de plantas con flores macho o androicas, de flores solo estaminadas; frutas entre 2,5 a $5 \mathrm{~kg}$ y bajo contenido de sólidos solubles totales. Los cultivares locales denominados Cartagena y Paraguanera, se siembran poco en plantaciones comerciales (Aular y Casares, 2011). Los frutos de Cartagena maduran fácilmente y son delicados para el transporte, mientras que los de Paragüanera presentan más resistencia en condiciones de poscosecha (FUSAGRI, to PRSV, a devastating disease that is transmitted by aphids (Ogata, et al., 2016). However, conventional breeding efforts to develop resistance to PRSV have not been entirely successful (Rimberia, et al., 2018). In Mexico, it has been observed that the Maradol cultivars and Red Lady can compensate for the loss of production due to the effects of PRSV for its high yields; however, the potential yield may vary according to the regions and management techniques used (Rivas et al., 2003).

In Venezuela, papaya is grown throughout the territory, in home gardens and in small and medium-sized production units (between 1.5 and 5 ha). Commercially, for the year of 2015 some 11,200 ha were planted, with a production of 203,000 $t$ (FEDEAGRO, 2019). The plants are tall; late flowering at $1 \mathrm{~m}$ high, approximately and high fruiting; certain percentage of plants with male or androic flowers, with only staminate flowers; fruits between 2.5 to $5 \mathrm{~kg}$ and low content of total soluble solids. The local cultivars called Cartagena and Paragüanera, are sown little in commercial plantations (Aular and Casares, 2011). The fruits of Cartagena ripen easily and are delicate for transport, while those from Paragüanera show more resistance in post-harvest conditions (FUSAGRI, 1984). In recent years "Maradol" has been widely accepted by farmers, merchants and consumers and has replaced local cultivars, satisfactorily adapting to Venezuela's edaphoclimatic conditions; however, the lack of availability and the high cost of imported seeds limit sowing 
1984). En los últimos años 'Maradol' ha sido aceptada ampliamente por los agricultores, comerciantes y consumidores y ha sustituido los cultivares locales, adaptándose satisfactoriamente a las condiciones edafoclimáticas de Venezuela; sin embargo, la falta de disponibilidad y el alto costo de las semillas importadas limitan la siembra en el país (Aular y Casares, 2011).

Una de las limitantes en la producción de lechosa ha sido la heterogeneidad de sexos en las plantaciones. En este sentido, Medina (1995) afirma que, según el tipo de flores presentes en la planta, estas pueden agruparse en: la forma androica, la cual presenta principalmente flores masculinas (tipo V); forma ginoica, con flores únicamente femeninas (tipo I) y la forma sexual andromonoica, con flores hermafroditas de los tipos II, III y IV, además de flores masculinas (IV+), pentandrias y carpeloides. Solo la adquisición de semilla certificada o la obtención artesanal de semilla a partir de plantas con un alto nivel de hermafroditismo garantizarán esta condición.

Según Alonso (1946), teniendo como base poblaciones del cultivar Maradol Roja, se puede llegar a la obtención de líneas mediante la selección de plantas elites andromonoicas (de flores hermafroditas), en las que se encuentren reunidos el mayor número de los caracteres deseables y fijar dichos caracteres por medio de autopolinizaciones, eliminando las plantas indeseables y conservando los árboles que correspondan a las características ideales. Las líneas in the country (Aular and Casares, 2011).

One of the limitations in papaya production has been the heterogeneity of the sexes in the plantations. In this sense, Medina (1995) affirms that, according to the type of flowers present in the plant, these can be grouped into: the androic form, which presents mainly male flowers (type V); Ginoic form, with only female flowers (type I) and the sexual andromonoecious form, with hermaphrodite flowers of types II, III and IV, in addition to male flowers $(\mathrm{IV}+)$, pentandries and carpeloids. Only the acquisition of certified seed or handmade collection of seed from plants with a high level of hermaphroditism will guarantee this condition.

According to Alonso (1946), having as a basis populations of the Red Maradol cultivar, lines can be obtained by selecting elite andromonoecious plants (with hermaphrodite flowers), in which the highest number of the desirable characters are gathered and set these characters through selfpollinations, eliminating undesirable plants and preserving trees that correspond to the ideal characteristics. Andromonoecious lines are the best medium to maintain the supply of pure seeds, which will give uniform trees in the plantations, adopting the method of bagging the flower buds before anthesis occurs, unless the plants are isolated (Storey, 1978). Also, the selection of segregating populations can reveal big possibilities of success, due to the big variability of genotypes and high heritability values (Silva $e t$ al., 2017; Silva et al., 2018). 
Rev. Fac. Agron. (LUZ). 2021, 38: 60-83. Enero-Marzo.

Vegas et al.

ISSN 2477-9407

andromonoicas son el mejor medio para mantener el abastecimiento de semillas puras, que darán árboles uniformes en las plantaciones, adoptando el método de embolsado de los botones florales antes que ocurra la antesis, a menos que las plantas se encuentren aisladas (Storey, 1978). Además, la selección de poblaciones segregantes pueden revelar grandes posibilidades de éxito, debido a la gran variabilidad de genotipos y altos valores de heredabilidad (Silva et al., 2017; Silva et al., 2018).

El objetivo del trabajo fue la selección de plantas andromonoicas del cultivar Maradol procedentes de diferentes fuentes y localidades, basada en las características morfológicas y agronómicas; así como la producción de semillas de buena calidad mediante autopolinizaciones, tomando en cuenta los problemas limitantes observados en las zonas productoras en los estados centrales de Venezuela. Estas actividades estuvieron enmarcadas dentro del Plan Nacional de Semillas, llevado a cabo dentro del INIA-CENIAP, Maracay, estado Aragua, durante el período 2008-2011.

\section{Materiales y métodos}

Diagnóstico en las zonas de producción de lechosa de los estados centrales

Entre los años 2008 y 2009, se seleccionaron 14 unidades de producción de los estados centrales Aragua (12), Carabobo (1) y Yaracuy (1) y en actividades directas con los productores, se recolectó la siguiente
The objective of the work was the selection of andromonoecious plants of the Maradol cultivar from different sources and localities, based on the morphological and agronomic features; as well as the production of good quality seeds through selfpollinations, taking into account the limiting problems observed in the producing areas in the central states of Venezuela. These activities were framed within the Plan Nacional de semillas, carried out within INIACENIAP, Maracay, Aragua state, during the 2008-2011 period.

\section{Materials and methods}

\section{Diagnosis in the papaya production areas of the central states}

Between the years of 2008 and 2009, 14 production units from the central states Aragua (12), Carabobo (1) and Yaracuy (1) were selected and in direct activities with the producers, the following information of interest was collected: cultivar used, distance sowing, agronomic management, problems that affected production, among others. The production units are located in Aragua state, in the localities of the Valles de Tucutunemo, San Francisco de Asís and Sector Casa Blanca in Múcura I, of Zamora municipality; Ocumare de la Costa of the Costa de Oro municipality and San Sebastián de los Reyes of the San Sebastián municipality. In Carabobo state, in the Montalbán municipality, and in Yaracuy state, La Guarura sector of the Salom municipality. 
información de interés: cultivar utilizado, distancia de siembra, manejo agronómico, problemas que afectaron la producción, entre otros. Las unidades de producción se encontraron localizadas en el estado Aragua, en las localidades de los Valles de Tucutunemo, San Francisco de Asís y Sector Casa Blanca en Múcura I, del municipio Zamora; Ocumare de la Costa del municipio Costa de Oro y San Sebastián de los Reyes del municipio San Sebastián. En el estado Carabobo, en el municipio Montalbán y en el estado Yaracuy, en el Sector la Guarura del municipio Salom.

\section{Selección de plantas} andromonoicas

A partir del año 2008, se comenzó la selección de plantas andromonoicas en poblaciones de 'Maradol' en el INIA-CENIAP, a partir de diferentes fuentes: 1) frutos de plantas híbridas de semillas del Caribe ${ }^{\circledR}$; 2) frutos seleccionados de una población 'Maradol'; y 3) callos embriogénicos in vitro, donados por el Instituto de Biotecnología de Plantas (IBP) de la Universidad Central Martha Abreu de las Villas, Cuba.

Un total de 162 plantas de estas poblaciones en primera generación, producidas por semillas o embriones somáticos in vitro fueron sembradas en campo y en condiciones protegidas. Las localidades se escogieron tomando en cuenta la ausencia de plantas enfermas con síntomas de virosis o bacteriosis, y se seleccionaron las plantas andromonoicas, de acuerdo con 14 criterios, previamente acordados para la fase vegetativa, de floración y de fructificación

\section{Selection of andromonoecious plants}

Since the year of 2008, the selection of andromonoecious plants started in populations of "Maradol" at INIA-CENIAP, from different sources: 1) fruits of hybrid plants of Caribe ${ }^{\circledR}$ seeds; 2) Fruits selected from a "Maradol" population; and 3) In vitro embryogenic calluses, donated by the Instituto de Biotecnologia de Plantas (IBP) of La Universidad Central "Martha Abreu" de las Villas, Cuba.

A total of 162 plants from these populations in the first generation, produced by seeds or in vitro somatic embryos were sown in the field and under protected conditions. The localities were chosen taking into account the absence of diseased plants with symptoms of virosis or bacteriosis, and the andromonoecious plants were selected, according to 14 criteria, previously agreed for the vegetative, flowering and fruiting phase (table 1). Also, 35 qualitative and quantitative features were considered using the International Board of Plant Genetic Resources (IBPGR, now Biodiversity International) (1988) descriptor for papaya for the characterization of the stem, leaf, flower and fruit: growth habit (HT), Stem color in the middle part (CT), stem pigmentation (PT), stem wartiness (VT), wartiness distribution (DVT), number of nodes (NNFt) at the first flower, stem diameter at harvest ( DTt, in $\mathrm{cm}$ ) and height of the plant at harvest (APt, in $\mathrm{cm}$ ), color of the petiole (CP), length of the leaf petiole $(\mathrm{LPH}$, in $\mathrm{cm})$, diameter of the petiole ( $\mathrm{DPh}$, in $\mathrm{mm}$ ), width of the mature leaf (AHM, in $\mathrm{cm}$ ), length 
Rev. Fac. Agron. (LUZ). 2021, 38: 60-83. Enero-Marzo.

Vegas et al.

(cuadro 1). Además, se consideraron 35 características cualitativas y cuantitativas empleando el descriptor para lechosa del International Board of Plant Genetic Resources (IBPGR, ahora Biodiversity International) (1988) para la caracterización del tallo, hoja, flor y fruto: habito de crecimiento (HT), color del tallo en la parte media (CT), pigmentación del tallo (PT), verrugosidad del tallo (VT), distribución de la verrugosidad (DVT), número de nudos (NNFt) a la primera flor, diámetro del tallo a cosecha (DTt, en $\mathrm{cm}$ ) y altura de la planta a cosecha (APt, en $\mathrm{cm}$ ), color del peciolo (CP), longitud del peciolo de la hoja ( $\mathrm{LPH}$, en $\mathrm{cm})$, diámetro del pecíolo ( $\mathrm{DPh}$, en $\mathrm{mm}$ ), ancho de la hoja madura (AHM, en $\mathrm{cm}$ ), longitud de la nervadura central ( $\mathrm{LNCh}$, en $\mathrm{cm}$ ), forma del lobo central de la hoja (FLCH), hendidura de los lobos (HL), color del limbo de la hoja haz (CLHH), forma del seno proximal del peciolo (FSP), número de lobos (NLh), tipo de hermafroditismo (TH), tipo de floración (TF), ramificación de la inflorescencia (RI), presencia de brácteas en el pedúnculo ( $\mathrm{PBP}$ ), color de la corola (CC), color del pedúnculo $(\mathrm{CP})$, color de la piel del fruto maduro (CPF), pigmentación secundaria del fruto (PSF), forma de inserción del pedúnculo en fruto (FIPF), textura del fruto (TF), forma del fruto $(\mathrm{FF})$, peso del fruto (PF, en gramos), longitud del fruto (LF, en $\mathrm{cm}$ ), diámetro del fruto (DF, en $\mathrm{cm}$ ), forma de la cavidad central del fruto (FCCF), diámetro de la cavidad central del fruto (DCCF, en $\mathrm{cm}$ ), longitud de la cavidad central del of the central rib ( $\mathrm{LNCh}$, in $\mathrm{cm}$ ), shape of the central leaf lobe (FLCH), cleft of the lobes (HL), color of the leaf blade limb (CLHH), shape of the proximal petiole sinus (FSP), number of lobes (NLh), type of hermaphroditism (TH), type of flowering (TF), branching of the inflorescence (IR), presence of bracts on the peduncle (PBP), color of the corolla (CC), color of the peduncle $(\mathrm{CP})$, skin color of the ripe fruit (CPF), secondary pigmentation of the fruit (PSF), shape of peduncle insertion in fruit (FIPF), fruit texture (TF), fruit shape $(\mathrm{FF})$, fruit weight $(\mathrm{PF}$, in grams), fruit length ( $\mathrm{LF}$, in $\mathrm{cm}$ ), fruit diameter ( $\mathrm{DF}$, in $\mathrm{cm}$ ), shape of the central fruit cavity (FCCF), diameter of the central fruit cavity (DCCF, in $\mathrm{cm})$, length of the central fruit cavity (LCCF, in $\mathrm{cm}$ ) and width of the pulp (AP, in $\mathrm{cm}$ ). For measurements: In $\mathrm{cm}$, a tape measure was used and in $\mathrm{mm}$, a vernier; and for the qualitative characteristics the scale proposed by the IBPGR was used. At least five measurements per characteristic were taken for each selected plant.

A total of 144 plants from seeds of the population of Valle Tucutunemo, in the second generation of selection, were planted and evaluated in the open field at Empresa de Producción Social Los Tacariguas, Guacara sector, Carabobo state. For the selection of the plants, 44 qualitative and quantitative characteristics were considered using the IBPGR descriptor for papaya (1988); also adding: length of the inflorescence peduncle (LPIf, in $\mathrm{cm}$ ), length of bracts (LBf, in $\mathrm{mm}$ ), length of 
Rev. Fac. Agron. (LUZ). 2021, 38: 60-83. Enero-Marzo.

Vegas et al.

ISSN 2477-9407

fruto (LCCF, en $\mathrm{cm}$ ) y ancho de pulpa (AP, en $\mathrm{cm})$. Para las mediciones: en $\mathrm{cm}$, se utilizó una cinta métrica y en $\mathrm{mm}$, un vernier; y para las características cualitativas se usó la escala propuesta por el IBPGR. Se tomaron al menos cinco mediciones por característica para cada planta seleccionada. hermaphrodite flower (LFHf, in $\mathrm{cm})$, length of staminate flower (LFEf, in cm), length of sepals (LSf, in $\mathrm{mm}$ ), calyx tube length (LTCf, in $\mathrm{cm}$ ), petal length (LPf, in $\mathrm{cm}$ ) and number of fruits (NFT). The identification of each selected plant was according to the number of row and corresponding plant.

\section{Cuadro 1. Criterios para la selección de plantas de lechosa según Alonso et al. (2009).}

Table 1. Criteria for the selection of papaya plants according to Alonso et al. (2009).

\begin{tabular}{ll}
\hline Criterio & Descripción \\
\hline 1 & Inicio a floración entre 3 -4 meses \\
2 & Altura de floración menor a $1 \mathrm{~m}$ \\
3 & Proporción de plantas ginoicas y andromonoicas \\
4 & Bajo porcentaje de esterilidad \\
5 & Inicio fructificación menor a 4 meses \\
6 & Altura de planta a la cosecha menor a $2 \mathrm{~m}$ \\
7 & Plantas sanas y vigorosas \\
8 & Con más de 40 frutos \\
9 & Fructificación a lo largo de la planta \\
10 & Rendimientos entre 84,5 y 86,2 kg.año ${ }^{-1}$ \\
11 & Peso de fruto entre 1,6 y $2,2 \mathrm{~kg}$ \\
12 & Forma de fruto alargado \\
13 & Ancho pulpa mayor a $3 \mathrm{~cm}$ \\
14 & Pulpa naranja-rojiza \\
\hline
\end{tabular}

Un total de 144 plantas procedentes de semillas de la población del Valle de Tucutunemo, en segunda generación de selección, se sembraron y evaluaron a campo abierto en la Empresa de Producción Social Los Tacariguas, sector Guacara, estado Carabobo. Para la selección

\section{Statistical analysis}

For the quantitative morphological characterization, five measurements were taken. An analysis of variance (ANAVAR) and a means test by Tukey $(\alpha=0.05)$ were performed in the second generation, according to Montgomery (1991). In 
Rev. Fac. Agron. (LUZ). 2021, 38: 60-83. Enero-Marzo.

Vegas et al.

ISSN 2477-9407

de las plantas se consideraron 44 características cualitativas y cuantitativas empleando el descriptor para lechosa del IBPGR (1988); adicionándose además: longitud del pedúnculo de la inflorescencia (LPIf, en $\mathrm{cm}$ ), longitud de brácteas (LBf, en $\mathrm{mm}$ ), longitud de flor hermafrodita (LFHf, en cm), longitud del flor estaminada (LFEf, en $\mathrm{cm}$ ), longitud de sépalos (LSf, en $\mathrm{mm}$ ), longitud del tubo del cáliz (LTCf, en cm), longitud de los pétalos (LPf, en $\mathrm{cm}$ ) y número de frutos (NFT). La identificación de cada planta seleccionada fue de acuerdo con el número de hilera y planta correspondiente.

\section{Análisis estadístico}

Para la caracterización morfológica cuantitativa se tomaron cinco mediciones. A la segunda generación se le realizó un análisis de la varianza (ANAVAR) y prueba de medias por Tukey $(\alpha=0,05)$, según Montgomery (1991). Además, se realizó un análisis de componentes principales de la varianza total (ACP). En la tabulación y procesamiento de los datos, se emplearon la hoja electrónica de cálculo MicrosoftC Excel (2007) y el software estadístico Infostat (2002).

Autopolinizaciones de las plantas seleccionadas

Se realizaron autopolinizaciones en flores hermafroditas elongatas de las plantas seleccionadas, tapando con bolsas de papel pequeñas $(15 \mathrm{~cm}$ de largo y $8 \mathrm{~cm}$ de ancho), hasta que el ovario se fecundara. En el caso de flores pentandrias, al abrir la flor se polinizaron con su propio polen o polen de otras flores de la misma planta, tomándose las anteras de cinco flores addition, an analysis of principal components of total variance (ACP) was performed. In the tabulation and data processing, the electronic spreadsheet Microsoft $(C$ Excel (2007) and the statistical software Infostat (2002) were used.

\section{Self-pollinations of plants selected}

Self-pollinations were carried out on elongated hermaphrodite flowers of the selected plants, covering with small paper bags $(15 \mathrm{~cm}$ long and $8 \mathrm{~cm}$ wide), until the ovary was fertilized. In the case of pentandrian flowers, when they opened the flower they pollinated themselves with their own pollen or pollen from other flowers of the same plant, taking the anthers of five flowers and gently shaking them over the stigma, as described by Alonso (1946). The event and date were identified. The number of curdled fruits was recorded.

\section{Results and discussion}

\section{Diagnosis of production areas in the central states}

In the 14 sampled production units, five hybrid genetic materials sown were identified: Red Maradol (2/14), Carmen (2/14) and Red Lady (1/14); cultivars: Cartagena Roja (4/14), Red Maradol (2/14); undefined materials: $5 / 14$. This information indicated the prevalent use of imported hybrid seeds in production units of longest surface, from 1.5 to 5 ha, and national seeds in smaller production units, from 1.5 to 2 ha. In most of the production units, fruits of orange pulp (mesocarp) were found (13/14) and only in one of these, 
y agitándolas suavemente sobre el estigma, tal y como lo describió Alonso (1946). Se identificó el evento y la fecha. Se registró el número de frutos cuajados.

\section{Resultados y discusión}

\section{Diagnóstico de las zonas de producción en los estados centrales}

En las 14 unidades de producción muestreadas, se identificaron cinco materiales genéticos sembrados, híbridos: Maradol Roja (2/14), Carmen (2/14) y Red Lady (1/14); cultivares: Cartagena Roja (4/14), Maradol Roja (2/14); materiales no definidos: 5/14. Esta información indicó el uso prevalente de semillas híbridas importadas en las unidades de producción de mayor superficie, de 1,5 a 5 ha, y de semillas nacionales en unidades de producción más pequeñas, de 1,5 a 2 ha. En la mayoría de las unidades de producción, se encontraron frutos de pulpa (mesocarpo) anaranjada (13/14) y solo en una de estas, se encontraron frutos de pulpa amarilla, en un material de origen desconocido. Esta tendencia ha sido señalada por otros autores como Aular y Casares (2011), quienes mencionaron que ha habido un gran avance tecnológico en este cultivo en el país, y que en las plantaciones comerciales se incluyen las prácticas de sustitución de la papaya criolla por semillas certificadas del grupo 'Maradol' y la siembra de dos o más plantas por punto para garantizar el mayor número de plantas hermafroditas. La misma situación fruits of yellow pulp were found, in a material of unknown origin. This trend has been pointed out by other authors such as Aular and Casares (2011), who mentioned that there has been a big technological advance in this crop in the country and that in commercial plantations the practices of substituting Creole papaya for seeds are included, certified from the "Maradol" group and the sowing of two or more plants per point to guarantee the highest number of hermaphrodite plants. The same situation has occurred in other countries, such as Mexico, where improved cultivars and hybrids predominate over native varieties, the latter being found only in family gardens for self-consumption (Hernández et al., 2019).

Among the main problems identified in the production units, the following can be mentioned:

1. The sowing of unselected cultivars in five plots or small "Conucos" (most common indigenous term to name the place where food is planted) with 4 four to 100 plants that looked heterogeneous.

2. High incidence of PRSV in 7 of the production units visited, affecting all the materials "Carmen", "Maradol", "Red Lady" and "Cartagena Roja" in the states of Aragua and Carabobo.

3. Low incidence of bacteriosis, affecting "Maradol" plants in Carabobo state, and the presence of the Asperisporium caricae fungus in fruits of the Cartagena cultivar, in Yaracuy state.

4. Male plants were found only in a local population of Cartagena and 
Rev. Fac. Agron. (LUZ). 2021, 38: 60-83. Enero-Marzo.

Vegas et al.

ISSN 2477-9407

ha ocurrido en otros países, como México, donde predominan los cultivares mejorados e híbridos sobre las variedades nativas, encontrándose estas últimas solamente en huertas familiares para autoconsumo (Hernández et al., 2019).

Entre los problemas principales identificados en las unidades de producción, se pueden mencionar los siguientes:

1. La siembra de cultivares no seleccionados en cinco parcelas o conucos pequeños con apenas cuatro a 100 plantas que lucieron heterogéneas.

2. Alta incidencia de PRSV en siete de las unidades de producción visitadas, afectando todos los materiales 'Carmen', 'Maradol', 'Red Lady' y 'Cartagena Roja' en los estados Aragua y Carabobo.

3. Baja incidencia de la bacteriosis, afectando plantas 'Maradol' en el estado Carabobo, y la presencia del hongo Asperisporium caricae en frutos del cultivar Cartagena, en el estado Yaracuy.

4. Se encontraron plantas masculinas solo en una población local de Cartagena y otra criolla; así como frutos carpeloides en el híbrido Red Lady.

En este estudio se corrobora que el PRSV continúa siendo un problema severo en lo que respecta a la sanidad del cultivo en Venezuela, y que la bacteriosis también afecta. Esta última debe ser tomada en cuenta debido a que puede ser diseminada por la semilla (Maselli, et al., 2010; Fernández, et al., 2008) another Creole; as well as carpeloid fruits in the Red Lady hybrid.

This study corroborates that PRSV continues being a severe problem regarding to crop health in Venezuela, and that bacteriosis also affects. This latter must be taken into account because it can be spread by the seed (Maselli, et al., 2010; Fernández, et al., 2008)

\section{Selection of andromonoecious plants}

From the 306 plants sown in the four assays, 17 andromonoecious plants were selected, which fulfilled most of the previously agreed criteria for the vegetative, flowering and fruiting phases (Alonso et al., 2009): Beginning of flowering between the three and four months from transplanting to the field, flowering height less than $80 \mathrm{~cm}$, expected ratio of gynoic/andromonoecious plants (2:1), except for plants from tissue culture, which were andromonoecious, and there were no plants with male flowers, low percentage of sterility, initiation of fruiting before four months, height from plant to harvest $<2 \mathrm{~m}$, robust appearance plants, large deep green leaves, fruiting throughout the plant, elongated and smooth fruits, width of pulp $>3 \mathrm{~cm}$, and orange-reddish pulp (tables 1 and 2).

The plants of population 1 had an APt between 1.4 and $1.7 \mathrm{~m}$, population 2 between 1.43 to $1.8 \mathrm{~m}$ and population 3 from 1.80 to $1.84 \mathrm{~m}$. Although the number of fruits on the tree stem was low for the first two populations from 38 to 45 for population 1 and from 20 to 38 in population 2 , the estimated 


\section{Selección de plantas andromonoicas}

De las 306 plantas sembradas en los cuatro ensayos se seleccionaron 17 plantas andromonoicas, las cuales cumplieron con la mayoría de los criterios previamente acordados para las fases vegetativa, floración y fructificación (Alonso et al., 2009): Inicio a floración entre los tres y cuatro meses del trasplante a campo, altura de floración menor de 80 $\mathrm{cm}$, proporción de plantas ginoicas/ andromonoicas esperada (2:1), a excepción de las plantas procedentes de cultivo de tejidos, las cuales fueron andromonoicas, y no hubo plantas con flores masculinas, bajo porcentaje de esterilidad, iniciación de la fructificación antes de los cuatro meses, altura de planta a cosecha $<$ a $2 \mathrm{~m}$, plantas de apariencia robusta, hojas grandes de color verde intenso, fructificación a lo largo de la planta, frutos alargados y lisos, ancho de pulpa $>$ a $3 \mathrm{~cm}$ y, pulpa naranjarojiza (cuadros 1 y 2 ).

Las plantas de la población 1 tuvieron una APt entre 1,4 y 1,7 $\mathrm{m}$, la población 2 entre 1,43 a 1,8 m y la población 3 de 1,80 a 1,84 m. Aunque el número de frutos en el tronco fue bajo para las dos primeras poblaciones, de 38 a 45 para la población 1 y de 20 a 38 en la población 2. Los rendimientos promedios estimados se encontraron dentro o ligeramente superiores al rango esperado (84,5 y 86,2 kg), siendo de $88,3 \mathrm{~kg}$ para la población 1 y 86,64 kg para la población 2 . En la población 3 , aun cuando presentó un mayor número de frutos, entre average yields were within or slightly above the expected range (84.5 and $86.2 \mathrm{~kg}$ ), being $88.3 \mathrm{~kg}$ for population 1 and $86.64 \mathrm{~kg}$ for population 2 .

In population 3 , even though it presented a higher number of fruits, between 52 and 56, the estimated yields were of $66.3 \mathrm{~kg}$, well below that described for the Maradol cultivar by Alonso et al. (2009) (data not shown).

The 24 qualitative characteristics of the stem, leaf, flower and fruit were similar in population selections 1 , 2 and 3: single stems, green to light gray or gray-brown in the middle part; green pigmentation of young stem (not suberized); little wartiness distributed at the base or throughout the internodes; hollow structure of petiole, pale green color, some with purple spots; shape of the central blade lobe sharp; deep cleft of lobes; leaf blade color green or dark green; shape of the proximal sinus of the closed or peeled petiole. Hermaphroditic type of tree with staminate flowers and few hermaphrodite flowers; type of flowering in inflorescences; branching of the intermediate inflorescence of 3 to 10 flowers; green color of peduncle and presence of bracts; corolla of cream color. Skin color of the ripe fruit from strong yellow to orange, with secondary green pigmentation; smooth fruit texture and in some cases intermediate; depressed, flattened, or pointy form of peduncle insertion. The fruits were elongated, with the obtuse apex and round central cavity (data not shown). However, in other studies that compared dioic genotypes of papaya and wild species of Vasconcelleas ( $V$. cauliflora and 
Rev. Fac. Agron. (LUZ). 2021, 38: 60-83. Enero-Marzo.

Vegas et al.

ISSN 2477-9407

52 y 56 , los rendimientos estimados fueron de $66,3 \mathrm{~kg}$, muy por debajo a lo descrito para el cultivar Maradol por Alonso et al. (2009) (datos no mostrados).
$V$. cundinamarcensis) they found significant variations in some of the qualitative characteristics, such as stem color, petiole color, shape of the proximal petiole sinus, leaves shape,

Cuadro 2. Descripción de las cuatro poblaciones de lechosa 'Maradol', a partir de las cuales se seleccionaron plantas andromonoicas.

Table 2. Description of the four "Maradol" papaya populations, from which andromonoecious plants were selected.

\begin{tabular}{|c|c|c|c|c|c|c|c|}
\hline Población & Localidad & Procedencia & Año & $\begin{array}{l}N^{\circ} \text { plantas } \\
\text { sembradas }\end{array}$ & $\begin{array}{c}\mathrm{N}^{\circ} \text { plantas } \\
\text { seleccionadas }\end{array}$ & $\begin{array}{c}\text { Andromonoicas/ } \\
\text { Ginoicas }\end{array}$ & Generación \\
\hline 1 & $\begin{array}{l}\text { San Francisco } \\
\text { de Asis, } \\
\text { estado Aragua }\end{array}$ & $\begin{array}{l}\text { Plantas } \\
\text { híbridas, } \\
\text { semillas del } \\
\text { Caribe }{ }^{\circledR}\end{array}$ & $\begin{array}{l}2008- \\
2009\end{array}$ & 56 & 03 & $2: 1$ & I \\
\hline 2 & $\begin{array}{l}\text { Valle de } \\
\text { Tucutunemo, } \\
\text { estado Aragua }\end{array}$ & $\begin{array}{l}\text { Frutos } \\
\text { seleccionados } \\
\text { en población }\end{array}$ & $\begin{array}{l}2009- \\
2010\end{array}$ & 96 & 07 & $2: 1$ & I \\
\hline 3 & $\begin{array}{l}\text { Unidad de } \\
\text { Recursos } \\
\text { Fitogenéticos, } \\
\text { estado Aragua } \\
\text { en casa de } \\
\text { malla }\end{array}$ & $\begin{array}{l}\text { Callo } \\
\text { embriogénico } \\
\text { In vitro }\end{array}$ & 2010 & 10 & 02 & $\begin{array}{l}\text { 1:0 } \\
\text { (Todas } \\
\text { andromonoicas) }\end{array}$ & I \\
\hline 4 & $\begin{array}{l}\text { Empresa de } \\
\text { Producción } \\
\text { Socialista Los } \\
\text { Tacarigua, } \\
\text { estado } \\
\text { Carabobo } \\
\text { Total }\end{array}$ & $\begin{array}{l}\text { Plantas } \\
\text { seleccionadas } \\
\text { en Valle de } \\
\text { Tucutunemo }\end{array}$ & $\begin{array}{l}2010- \\
2011\end{array}$ & 144 & 17 & $2: 1$ & II \\
\hline
\end{tabular}

Las 24 características cualitativas del tallo, hoja, flor y fruto, fueron similares en las selecciones de la población 1, 2 y 3: tallos únicos, de color verde a gris claro o gris-marrón en la parte media; pigmentación verde del tallo joven (no suberizado); poca verrugosidad distribuida en peduncle color of the inflorescence and flower color (Kaluram et al., 2018).

In the San Francisco de Asís assay, the fruits from female flowers presented extremely small and round sizes, not very commercial. These fruits, out of type, were not observed in the other populations and this 
la base o en todo el entrenudo; estructura hueca del peciolo, de color verde pálido, algunas con manchas púrpuras; forma del lobo central de la hoja agudo; hendidura de los lobos muy profunda; color del limbo de la hoja haz verde o verde oscuro; forma del seno proximal del peciolo cerrado o peltado. Tipo de hermafroditismo del árbol con flores estaminadas y pocas flores hermafroditas; tipo de floración en inflorescencias; ramificación de la inflorescencia intermedia de 3 a 10 flores; color del pedúnculo verde y presencia de brácteas; color de la corola crema. Color de la piel del fruto maduro de amarillo fuerte a naranja, con pigmentación secundaria verde; textura del fruto lisa y en algunos casos intermedia; forma de inserción del pedúnculo deprimida, aplanada o punteaguda. Los frutos fueron elongados, con el ápice obtuso y cavidad central redonda (datos no mostrados). Sin embargo, en otros estudios que compararon genotipos dioicos de lechosa y especies silvestres de Vasconcelleas ( $V$. cauliflora y $V$. cundinamarcensis) encontraron variaciones significativas en algunas de las características cualitativas, tales como color del tallo, color del pecíolo, forma del seno proximal del pecíolo, forma de las hojas, color del pedúnculo de la inforescencia y color de la flor (Kaluram et al., 2018).

En el ensayo de San Francisco de Asís, los frutos procedentes de flores femeninas presentaron tamaños extremadamente pequeños y redondos, poco comerciales. Estos frutos, fuera de tipo, no se observaron en las demás poblaciones y esto was possibly due to the hybrid origin of this seed. These gynoic plants were not considered and self-pollinations were carried out with elongatetype hermaphrodite flowers perfect for obtaining seeds for successive generations.

During the period between 20102011, in the assay of Empresa de Producción Socialista Los Tacariguas, from the 144 plants planted (population 4), the five most prominent andromonoecious plants were selected according to their morphological and agronomic features, called H23-15, H23-19, H24-11, H26-8 and H33-2 (table 2).

The qualitative characteristics of the stem, leaf, flower and fruit were similar in the selected plants of population 4 : single stems, gray-brown color in the middle part, and green pigmentation of the young stem (not suberized), with little wartiness distributed in the base of the selections H23-15 and H33-2 and throughout the internode for the rest. Green and purple petiole, shape of central lobe of the leaf sharp, cleft of the lobes very deep, leaf blade color dark green, and shape of the proximal sinus of the closed petiole. Hermaphroditism type of tree with staminate flowers and few hermaphrodite flowers; type of flowering in inflorescences, with ramification of the intermediate inflorescence of 3 to 10 flowers; green peduncle with presence of bracts and corolla of cream color. Strong yellow to orange skin color of ripe fruit, with secondary green pigmentation; smooth fruit texture, round central fruit cavity and depressed peduncle insertion shape. 
Rev. Fac. Agron. (LUZ). 2021, 38: 60-83. Enero-Marzo.

Vegas et al.

ISSN 2477-9407

posiblemente se debió a la procedencia híbrida de esta semilla. Estas plantas ginóicas no fueron consideradas y se realizaron autopolinizaciones con flores hermafroditas tipo elongata perfecta para la obtención de semillas para las sucesivas generaciones.

Durante el período 2010-2011, en el ensayo de la Empresa de Producción Socialista Los Tacariguas, de las 144 plantas sembradas (población 4), se seleccionaron las cinco plantas andromonoicas más destacadas de acuerdo con sus características morfológicas y agronómicas, denominadas H23-15, H23-19, H2411, H26-8 y H33-2 (cuadro 2).

Las características cualitativas del tallo, hoja, flor y fruto fueron similares en las plantas seleccionadas de la población 4: tallos únicos, de color gris-marrón en la parte media, pigmentación verde del tallo joven (no suberizado), con poca verrugosidad distribuida en la base de las selecciones H23-15 y H33-2 y en todo el entrenudo para las restantes. Color del pecíolo verde y púrpura, forma del lobo central de la hoja agudo, hendidura de los lobos muy profunda, color del limbo de la hoja haz verde oscuro, y forma del seno proximal del peciolo cerrado. Tipo de hermafroditismo del árbol con flores estaminadas y pocas flores hermafroditas; tipo de floración en inflorescencias, con ramificación de la inflorescencia intermedia de 3 a 10 flores; color del pedúnculo verde con presencia de brácteas $\mathrm{y}$, color de la corola crema. Color de la piel del fruto maduro amarillo fuerte a naranja, con pigmentación secundaria verde; textura del fruto lisa, cavidad central
Regarding to the shape of the fruit, these were elongated in selections H24-11 and H26-8; between cylindrical and elongated for H33-2; cylindrical at 23-15 and piriform at H23-19. These qualitative characteristics were similar to the population of the Tucutunemo Valley that gave rise to them. Alonso et al. (2009) mention that the typical fruits of the Maradol cultivar would be elongated, however, consumers and producers also prefer cylindrical and piriform forms with a smaller internal cavity than that produced by the fruits of female plants and therefore of higher value of the market due to its weight and resistance to handling (Silva et al., 2018).

The analysis of principal components showed clearly how there is a wide variability between the selected materials, highlighting each of them by a group of highly related quantitative variables.

In the case of $\mathrm{H} 23-15$ it was observed how this material was characterized by the high relationship between APt and NNFt. H33-2 and H23-19 shared similarities in stem, leaf, flower and fruit characteristics, such as: DTt, LCCf, LTCf, LPf, and LNCHh; coinciding the LCCf with the elongated fruits of H33-2 and the piriformis of $\mathrm{H} 23-19$. In selection H24-11, high values were observed in morphological variables of stem, leaves, flowers and fruits, such as: $\mathrm{DPh}, \mathrm{LPHh}, \mathrm{AHMh}, \mathrm{LBf}$ and DVT, together with a high API, common in elongated fruits. For its part, H268 was the selection with the highest NFT, characterized by the presence of 
del fruto redonda y forma de inserción del pedúnculo deprimida.

Con respecto a la forma del fruto, estos fueron elongados en las selecciones H24-11 y H26-8; entre cilíndricos y elongados para H332; cilíndricos en 23-15 y piriformes en H23-19. Estas características cualitativas fueron similares a la población de procedencia del Valle de Tucutunemo que les dio origen. Alonso et al. (2009) mencionan que los frutos típicos del cultivar Maradol serían elongados, sin embargo, los consumidores y productores también prefieren las formas cilíndricas y piriformes con una cavidad interna menor que la producida por los frutos de las plantas femeninas y por lo tanto de mayor valor de mercado por su peso y resistencia al manejo (Silva et al., 2018).

El análisis de componentes
principales dejó ver claramente como existe una amplia variabilidad entre los materiales seleccionados, resaltando cada uno de ellos por un grupo de variables cuantitativas altamente relacionadas.

En el caso de H23-15 se observó como este material se caracterizó por la alta relación entre la APt y el NNFt. H33-2 y H23-19 compartieron similitudes en características del tallo, hoja, flor y frutos, tales como: DTt, LCCf, LTCf, LPf, y LNCHh; coincidiendo la LCCf con los frutos elongados de H33-2 y los piriformes de H23-19. En la selección H24-11 se observaron valores altos en variables morfológicas de tallo, hojas, flores y frutos, como: DPh, LPHh, AHMh, LBf y DVT, aunado a un alto API, común elongated fruits and lower LPf (figure $1)$.

Significant differences were observed between the selections regarding to eight variables, standing out H33-2 with the highest values related to the leaves ( $\mathrm{LPHh}, \mathrm{DPh}$, AHMh, LNCh), followed by H23-15 and H24-11. In the same way, these three materials presented flowers of larger (higher) size (LPIf, LTCf, LPf). H23-15 stands out in terms of LCCf, regarding to the other plants. Materials H23-19 and H26-8 had the lowest values of these characteristics (table 3).

On the other hand, there were no significant differences between selections in relation to the characteristics: NLh between 11 and $11.60(\mathrm{p}=0.18)$; LBf between 0.82 and $1.48 \mathrm{~mm}(\mathrm{p}=0.11)$; LFHf, between 4.46 and $4.70 \mathrm{~cm}(\mathrm{p}=0.24)$; LFEf between 3.76 and $4.10 \mathrm{~cm}(\mathrm{p}=$ 0.50); LSf, between 0.20 and 0.32 $\mathrm{mm}(\mathrm{p}=0.64), \mathrm{PF}$ between 1.42 and $1.80 \mathrm{~kg}(\mathrm{p}=0.85) ; \mathrm{LF}$ between 21.25 and $24.75 \mathrm{~cm}(\mathrm{p}=0.35)$; DF between 11.04 and $13 \mathrm{~cm}(\mathrm{p}=0.78)$, although the average of the longest and widest fruit corresponds to the material H2315; DCCF between 4 and $4.98 \mathrm{~cm} \mathrm{(p=}$ $0.96)$ and APD between 3.25 and 3.65 $(\mathrm{p}=0.75)$.

Regarding to the quantitative characteristics of yield, of the five plants selected, the selections H2315, H33-2 and H26-8 stood out for producing 50, 51 and 64 fruits; with average weights $1.7 ; 1.8$ and $1.5 \mathrm{~kg}$, respectively. The estimated yields were between 83 and 98.5 kg.plant ${ }^{-1}$. These plants also had the highest 
Rev. Fac. Agron. (LUZ). 2021, 38: 60-83. Enero-Marzo.

Vegas et al.

ISSN 2477-9407

en frutos elongados. Por su parte, H26-8 fue la selección con el mayor NFT, caracterizada por la presencia de frutos de forma elongada y menor LPf (figura 1). number of nodes to the first flower, 109 to 122 . The H33-2 selection had the highest DTt $(64 \mathrm{~cm})$ and flowering height $(78 \mathrm{~cm})$ and also, higher leaf and flower dimensions. Selection H26-

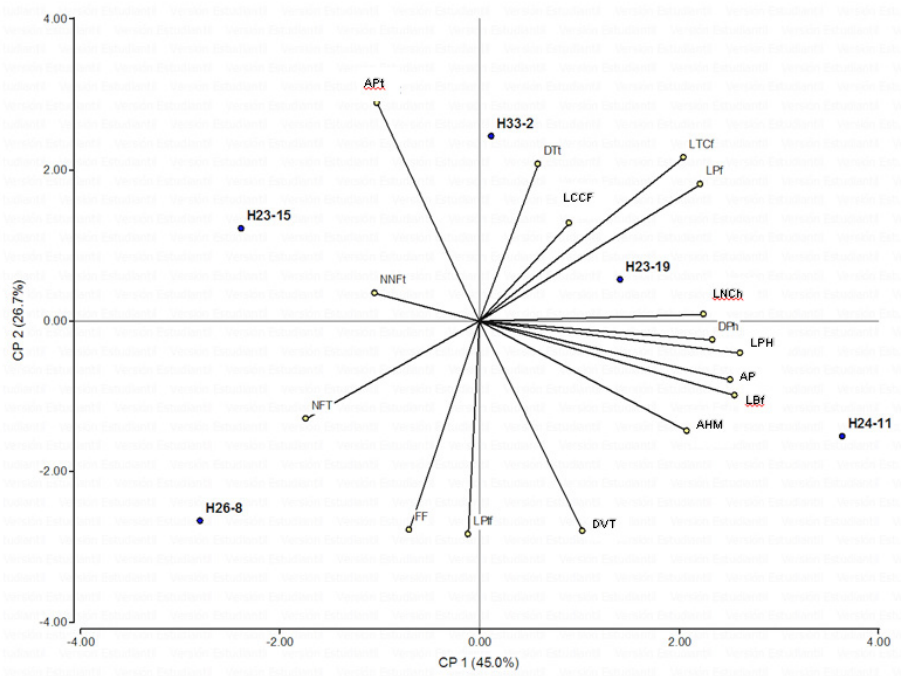

Figura 1. Distribución de las 16 variables originales sobre los componentes principales de las plantas de lechosa seleccionadas en la Empresa de Producción Social Los Tacariguas. APt: Altura de planta a cosecha; DTt: Diámetro del tallo a cosecha; LCCf: Longitud cavidad central de fruto; LTCf: Longitud tubo del cáliz; LPf: Longitud de pétalos; LNCH: Longitud de la nervadura central; DPh: Diámetro del pecíolo; LPH: Longitud del pecíolo de la hoja; LBf: Longitud de brácteas; AP: ancho de pulpa izquierda; NNFt: Número de nudos a la primera flor; AHM: Ancho de la hoja madura; DVT: Distribución de la verrugosidad del tallo; LPIf: Longitud del pedúnculo de la inflorescencia; NFT: Número de frutos; FF: Forma del fruto.

Figure 1. Distribution of the 16 original variables about papaya plants selected at Empresa de Producción Social Los Tacariguas. APt: Height plant at harvest; DTt: Diameter of the stem at harvest; LCCf: Length of the central cavity of the fruit; LTCf: Calyx tube length; LPf: Length of petals; LNCH: Length of the central rib; DPh: Petiole diameter; LPH: length of leaf petiole; LBf: Length of bracts; AP: width of left pulp; NNFt: Number of nodes to the first flower; AHM: Width of the mature leaf; DVT: Distribution of stem wartiness; LPIf: Length of the peduncle of the inflorescence; NFT: Number of fruits; FF: Fruit shape. 
Rev. Fac. Agron. (LUZ). 2021, 38: 60-83. Enero-Marzo.

Vegas et al.

ISSN 2477-9407

Se observaron diferencias

8 obtained the smallest dimensions of significativas entre las selecciones con respecto a ocho variables, destacándose H33-2 con los mayores valores relacionados con las hojas (LPHh, DPh, AHMh, LNCh), seguido de H23-15 y H24-11. De la misma manera, estos tres materiales presentaron flores de mayor tamaño (LPIf, LTCf, LPf). Se destaca H2315 en cuanto a la LCCf, con respecto a las demás plantas. Los materiales H23-19 y H26-8 tuvieron los menores valores de estas características (cuadro 3). the leaf, flower and stem; however, it had the highest amount of fruit. All the selections had APt less than or equal to $2 \mathrm{~m}$. The selections H23-19 and H24-11 produced lower amount fruits, 30 and 45 fruits.plant ${ }^{-1}$ from 1.4 to $1.5 \mathrm{~kg}$; and the estimated yields were the lowest, from 42.5 to $67.8 \mathrm{~kg}$; respectively NNFt was also less than 87 and 106.

Kaluham et al. (2018) point out that the papaya germplasm shows moderate to high variation in morphological characteristics,

Cuadro 3. Valores medios de las variables cuantitativas significativas en plantas de lechosa seleccionadas en la Empresa de Producción Socialista Los Tacariguas, Guacara, estado Carabobo.

Table 3. Medium values of the significant quantitative variables in selected papaya plants in at Empresa de Producción Socialista Los Tacariguas, Guacara, Carabobo state.

\begin{tabular}{ccccccccc}
\hline Selección & LPH $(\mathrm{cm})$ & DPh $(\mathrm{mm})$ & AHM $(\mathrm{cm})$ & LNCh $(\mathrm{cm})$ & LPIf $(\mathrm{cm})$ & LTCf $(\mathrm{cm})$ & LPf $(\mathrm{cm})$ & LCCF $(\mathrm{cm})$ \\
\hline H33-2 & $100,40 \mathrm{a}$ & $17,79 \mathrm{a}$ & $84,50 \mathrm{a}$ & $57,50 \mathrm{a}$ & $1,68 \mathrm{ab}$ & $1,42 \mathrm{a}$ & $2,96 \mathrm{a}$ & $14,33 \mathrm{~b}$ \\
$\mathrm{H} 23-15$ & $87,30 \mathrm{~b}$ & $15,01 \mathrm{bc}$ & $71,18 \mathrm{~b}$ & $49,54 \mathrm{~b}$ & $1,74 \mathrm{ab}$ & $1,46 \mathrm{a}$ & $3,12 \mathrm{a}$ & $19,00 \mathrm{a}$ \\
$\mathrm{H} 24-11$ & $86,00 \mathrm{~b}$ & $16,17 \mathrm{~b}$ & $70,50 \mathrm{~b}$ & $54,70 \mathrm{a}$ & $1,54 \mathrm{ab}$ & $1,44 \mathrm{a}$ & $3,02 \mathrm{a}$ & $16,10 \mathrm{ab}$ \\
$\mathrm{H} 23-19$ & $76,60 \mathrm{c}$ & $14,40 \mathrm{c}$ & $70,64 \mathrm{~b}$ & $47,36 \mathrm{~b}$ & $1,92 \mathrm{a}$ & $1,22 \mathrm{~b}$ & $2,00 \mathrm{c}$ & $14,33 \mathrm{~b}$ \\
$\mathrm{H} 26-8$ & $74,40 \mathrm{c}$ & $14,10 \mathrm{c}$ & $70,50 \mathrm{~b}$ & $45,34 \mathrm{~b}$ & $1,46 \mathrm{~b}$ & $1,34 \mathrm{ab}$ & $2,38 \mathrm{~b}$ & $14,00 \mathrm{~b}$ \\
$\mathrm{CV}$ & 4,79 & 5,08 & 7,09 & 4,76 & 12,52 & 5,44 & 6,18 & 4,91 \\
$\mathrm{R}^{2}$ & 0,84 & 0,74 & 0,50 & 0,78 & 0,31 & 0,56 & 0,87 & 0,74 \\
$\mathrm{p}$ & $0,00^{* *}$ & $0,00^{* *}$ & $0,00^{* *}$ & $0,00^{* *}$ & $0,02^{*}$ & $0,00^{* *}$ & $0,00^{* *}$ & $0,00^{* *}$ \\
\hline
\end{tabular}

*Valores con letras iguales en las columnas no son estadísticamente significativos ( $>00,05)$. LPH: Longitud del peciolo de la hoja; DPh: Diámetro del pecíolo de la hoja; AHM: Ancho de la hoja madura; LNCh: Longitud de la nervadura central; LPIf: Longitud del pedúnculo de la inflorescencia; LTCf: Longitud tubo del cáliz; LPf: Longitud pétalos; LCCF: Longitud cavidad central del fruto.

* Values with equal letters in the columns are not statistically significant (P>0.05). LPH:Leaf petiole length; DPh: Diameter of leaf petiole; AHM:Ripe leaf width; LNCh:Center rib length; LPIf:Inflorescence peduncle length; LTCf:Calyx tube length; LPf:Petals length; LCCF: Central cavity length of the fruit. 
Por otro lado, no hubo diferencias significativas entre selecciones con relación a las características: NLh entre 11 y 11,60 ( $p=0,18)$; LBf entre 0,82 y $1,48 \mathrm{~mm}(\mathrm{p}=0,11)$; LFHf, entre 4,46 y $4,70 \mathrm{~cm}(\mathrm{p}=0,24)$; LFEf entre 3,76 y $4,10 \mathrm{~cm}(\mathrm{p}=0,50)$; LSf, entre 0,20 y $0,32 \mathrm{~mm}(\mathrm{p}=0,64)$, PF entre 1,42 y $1,80 \mathrm{~kg}(\mathrm{p}=0,85) ; \mathrm{LF}$ entre 21,25 y $24,75 \mathrm{~cm}(\mathrm{p}=0,35) ;$ DF entre 11,04 y 13 $\mathrm{cm}(\mathrm{p}=0,78)$, aunque el promedio de fruto más largo y ancho correspondió con el material H23-15; DCCF entre 4 y $4,98 \mathrm{~cm}(\mathrm{p}=0,96)$ y APD entre 3,25 y $3,65(\mathrm{p}=0,75)$.

Con respecto a las características cuantitativas de rendimiento, de las cinco plantas seleccionadas se destacaron las selecciones H23-15, H33-2 y H26-8 por producir 50, 51 y 64 frutos; con pesos promedios 1,7; 1,8 y $1,5 \mathrm{~kg}$, respectivamente. Los rendimientos estimados estuvieron entre 83 y 98,5 kg.planta ${ }^{-1}$. Estas plantas además tuvieron el mayor número de nudos a la primera flor, 109 a 122. La selección H33-2 tuvo el mayor DTt $(64 \mathrm{~cm})$ y altura de floración (78 $\mathrm{cm}) \mathrm{y}$, además, mayores dimensiones de hoja, y de flor. La selección H26-8 obtuvo las menores dimensiones de la hoja, flor y tallo; sin embargo, tuvo la mayor cantidad de frutos. Todas las selecciones tuvieron APt menores o iguales a $2 \mathrm{~m}$. Las selecciones H23-19 y H24-11 produjeron menor cantidad de frutos, 30 y 45 frutos.planta ${ }^{-1}$, de 1,4 a $1,5 \mathrm{~kg}$; y los rendimientos estimados fueron los más bajos, de 42,5 a 67,8 kg; respectivamente. NNFt también fue menor de 87 y 106.

Kaluham et al. (2018) señalan que el germoplasma de lechosa muestra such as leaf shape and size, types of inflorescences and flowers, which vary according to the sex of the plant, shape and size of the fruit and the reaction to pests and diseases. They emphasize that the most diverse and economically important characteristics are related to flower and fruit, and they observed a significant amount of morphological diversity in petiole length, flower size, length and diameter of the fruit, index of the central cavity of the fruit and seed surface. On the other hand, Silva et al. (2017) obtained significant differences for all the variables evaluated, showing high genotypic variability between the accessions. The variables plant height, the height of the first insertion of the fruit, the greatest thickness of the fruit pulp, the length and diameter of the fruit presented heritability higher than $80 \%$, indicating that is possible to achieve significant advances in genetic improvement, through a simple selection process in the segregating generations. The variables fruit mass, fruit diameter and plant height were the ones with the highest contribution to genetic diversity. Therefore, these variables must be included in the plant breeding programs of the species. The IBPGR papaya descriptors were used in both references, but the materials evaluated were of very different types. In our research, the results indicated a high variability in some of the quantitative morphological characteristics analyzed, which can be explained by the different origins of the "Maradol" populations. This variability represents an advantage for the plant breeding of the cultivar, 
de moderada a alta variación en las características morfológicas, tales como, forma y tamaño de la hoja, tipos de inflorescencias y flores, que varían de acuerdo al sexo de la planta, forma y tamaño del fruto y la reacción a plagas y enfermedades. Enfatizan que las características más diversas y económicamente importantes están relacionadas a la flor y al fruto, y observaron una cantidad significativa de diversidad morfológica en longitud del pecíolo, tamaño de la flor, longitud y diámetro de la fruta, índice de la cavidad central del fruto y superficie de la semilla. Por otro lado, Silva et al. (2017) obtuvieron diferencias significativas para todas las variables evaluadas, mostrando alta variabilidad genotípica entre las accesiones. Las variables altura de planta, la altura de primera inserción de fruto, el mayor grosor de la pulpa de la fruta, la longitud y el diámetro de la fruta presentaron una heredabilidad superior al $80 \%$, indicando que es posible lograr avances significativos en la mejora genética, mediante un sencillo proceso de selección en las generaciones segregantes. Las variables masa del fruto, diámetro del fruto y altura de la planta fueron las de mayor contribución a la diversidad genética. Por lo anterior estas variables deben ser incluidas en los programas de mejoramiento genético de la especie. En ambas referencias se usaron los descriptores de papaya del IBPGR, pero los materiales evaluados fueron de muy diversos tipos. En nuestra investigación, los resultados indicaron una alta variabilidad en algunas de las características due to the high correlation between the phenological and production features, the high heritability of some of the characteristics and the inherent phenotypic plasticity in terms of sex, flowers and fruits that the papaya presents, as the reported by Kaluran et al. (2018) and Silva et al. (2018).

The 17 selected plants had morphological and agronomic features similar to those described for the Maradol cultivar (Ramos and Ramos, 2002; Alonso et al., 2009), considering that in addition to the genetic profile, the edaphoclimatic conditions, and the agronomic management in each plot should be taken into account. These selections form the basis for knowing the characteristics of these populations and guiding the development of new genotypes. Nowadays they are kept at INIA to continue the selection and plants are supplied to farmers.

\section{Conclusions}

The selected plants showed similar quantitative and qualitative descriptive characteristics similar to those of Maradol cultivar, among them, they presented low height (less than $2 \mathrm{~m}$ ), stem diameter up to 64 $\mathrm{cm}$, number, weight, shape and color of fruits that allow to guarantee the requirements from the local market, and good yields. The significant variation in some of the quantitative variables, between and within populations, can be used to continue fixing some characters, through selfpollination, for the development of improved lines, adapted to our edaphoclimatic conditions. 
Rev. Fac. Agron. (LUZ). 2021, 38: 60-83. Enero-Marzo.

Vegas et al.

ISSN 2477-9407

morfológicas

cuantitativas

analizadas, que se puede explicar por las diferentes procedencias de las poblaciones de "Maradol". Esta variabilidad representa una ventaja para el mejoramiento genético del cultivar, dada la alta correlación entre los rasgos fenológicos y de producción, la elevada heredabilidad de algunas de las características y la inherente plasticidad fenotípica en cuanto a sexo, flores y frutos que presenta la lechosa, como lo reportan Kaluran et al. (2018) y Silva et al. (2018).

Las 17 plantas seleccionadas tuvieron características morfológicas y agronómicas similares a las descritas para el cultivar Maradol (Ramos y Ramos, 2002; Alonso et al., 2009), considerando que además del perfil genético, habría que tomar en cuenta las condiciones edafoclimáticas, y el manejo agronómico en cada parcela. Estas selecciones constituyen la base para conocer las características de estas poblaciones y orientar el desarrollo de nuevos genotipos. Actualmente se conservan en el INIA para continuar la selección y se suministran plantas a los agricultores.

\section{Conclusiones}

Las plantas seleccionadas mostraron características descriptivas cuantitativas y cualitativas similares al cultivar Maradol, entre ellas, presentaron altura baja (menor de $2 \mathrm{~m}$ ), diámetro del tallo de hasta $64 \mathrm{~cm}$., número, peso, forma y color de frutos que permiten garantizar las exigencias del mercado local, y buenos rendimientos. La variación

\section{Recommendations}

The control of the plantations used for the selection is essential for the verification of the absence of bacterial diseases and the use of laboratory procedures for the screening of pathogens. Similar efforts should be made to select plants from other cultivars that are more tolerants to PRSV to satisfy demand in high incidence areas.

\section{Financing source}

Financing through the subproject "Plant breeding of the papaya Carica papaya $L$. in producing areas of the central, eastern and western areas of the country, using conventional techniques". Code ID-CNS-0800106 (Year 2008), and the action "Plant breeding of the papaya Carica papaya $L$ in producing areas of the central zone, using conventional and biotechnological techniques". Code 10-03-02-01 (Years 2009 to 2012). Plan Nacional de Semillas. INIA.

Table 1. Criteria for the selection of papaya plants according to Alonso et al. (2009).

Table 2. Description of the four "Maradol" papaya populations, from which andromonoecious plants were selected.

Table 3. Medium values of the significant quantitative variables in selected papaya plants in at Empresa de Producción Socialista Los Tacariguas, Guacara, Carabobo state.

Figure 1. Distribution of the 16 original variables about papaya plants 
Rev. Fac. Agron. (LUZ). 2021, 38: 60-83. Enero-Marzo.

Vegas et al.

significativa en algunas de las variables cuantitativas, entre y dentro de las poblaciones puede ser usada para continuar fijando algunos caracteres, mediante autopolinizaciones, para el desarrollo de líneas mejoradas, adaptadas a nuestras condiciones edafoclimáticas.

\section{Recomendaciones}

La fiscalización de las plantaciones utilizadas para la selección es esencial para la verificación de la no presencia de enfermedades bacterianas y el uso de procedimientos de laboratorio para el despistaje de patógenos. Esfuerzos similares deben darse para la selección de plantas de otros cultivares que sean más tolerantes al PRSV para satisfacer la demanda en zonas de alta incidencia.

\section{Fuente de financiación}

Financiamiento a través del subproyecto "Mejoramiento genético de la lechosa Carica papaya L. en zonas productoras de la zona central, oriente y occidente del país, mediante técnicas convencionales. Código IDCNS-0800106 (Año 2008), y la acción "Mejoramiento genético de la lechosa Carica papaya L. en zonas productoras de la zona central, mediante técnicas convencionales y biotecnológicas. Código 10-03-02-01 (Años 2009 al 2012). Plan Nacional de Semillas. INIA.

\section{Literatura citada}

Alonso, R. 1946. Observaciones sobre el cultivo y mejoramiento de la fruta bomba (Carica papaya L.). Est. Exp. Agron. Boletin N ${ }^{\circ}$ 67. 160 p. selected at Empresa de Producción Social Los Tacariguas. APt: Height plant at harvest; DTt: Diameter of the stem at harvest; LCCf: Length of the central cavity of the fruit; LTCf: Calyx tube length; LPf: Length of petals; LNCH: Length of the central rib; DPh: Petiole diameter; LPH: length of leaf petiole; LBf: Length of bracts; AP: width of left pulp; NNFt: Number of nodes to the first flower; AHM: Width of the mature leaf; DVT: Distribution of stem wartiness; LPIf: Length of the peduncle of the inflorescence; NFT: Number of fruits; FF: Fruit shape.

\section{End of English Version}

Alonso, M., Y. Tornet, R. Ramos, E. Farres y D. Rodríguez. 2009. Evaluación de dos híbridos de papaya introducidos en Cuba. Agronomía Costarricense $32: 267-274$.

Aular, J. y M. Casares. 2011. Consideraciones sobre la producción de frutas en Venezuela. Rev. Bras. Frutic. 33: 187-198.

Confederación de Asociaciones de Producción Agropecuaria (FEDEAGRO). 2019. Estadísticas de producción. Disponible en: https://fedeagro.org/estadisticasagricolas/produccion-agropecuaria/ produccion/. Fecha de consulta: febrero 2019

Fernández, T., L. Rubio, O. Carballo y E. Marys. 2008. Genetic variation of papaya ringspot virus in Venezuela. Arch. Virol. 153: 343-349.

Fundación Servicio para el Agricultor (FUSAGRI). 1984. La Lechosa. Serie Petróleo y Agricultura. $\mathrm{N}^{\circ} 6.70$ p.

Hernández, G., A. Soto, E. García, A. Pérez, M. Rocandio y L. 2019. Córdova. 


\section{Rev. Fac. Agron. (LUZ). 2021, 38: 60-83. Enero-Marzo.}

\section{Vegas et al.}

Variación morfológica in situ de Carica papaya nativa de México. Rev. Fitotec. Mex. 42 (1): 47-55.

International Board for Plant Genetic Resources (IBPGR). 1988. Descriptors for papaya. Rome. $34 \mathrm{p}$.

InfoStat. 2002. InfoStat, versión 1.1. Manual del Usuario. Grupo InfoStat, FCA, Universidad Nacional de Córdoba. Primera Edición, Editorial Brujas Argentina.

Kaluram, J., S. Singh, A. Goswami, P. Singh, Z. Hussain y A. Singh. 2018. Genetic diversity in qualitative and quantitative traits of papaya. Indian J. Hort., 75(2):165-171.

Maselli, A., C. Rosales, Y. Guevara y Z. Suarez. 2010. Comportamiento de materiales de los géneros Carica y Vasconcellea frente Erwinia papayae, Meloidogyne incognita y Rotylenchulus reniformis. Rev. Protección Veg. 25:157-165.

Medina. J. 1995. Cultura do mamoeiro. En Mamao. Serie Frutas Tropicais. $2^{\text {da }}$ Edición. ITAL-CAMPINAS. Brasil. $367 \mathrm{p}$.

Microsoft Office Excel. 2007. Manual del usuario. Microsoft Corporation.

Montgomery, D. 1991. Diseño y Análisis de Experimentos. Grupo Edit. Iberoamérica. $351 \mathrm{p}$.

Ogata, T., S. Yamanaka, M. Shoda, N. Urasaki y T. Yamamoto. 2016. Current status of tropical fruit breeding and genetics for three tropical fruit species cultivated in Japan: pineapple, mango, and papaya. Breeding science, 66(1), 6981.
Ramos, R. y J. Ramos. 2002. Instrucciones técnicas para el cultivo de la papaya Maradol Roja. Manual técnico. Ed. Empresa de Semillas, MINAG. Cuba. $34 \mathrm{p}$.

Rimberia, F., F. Ombwara, N. Mumo y E. Ateka. 2018. Genetic Improvement of papaya (Carica papaya L.). In: Al-Khayri, J. M., S. M. Jain y D. V. Johnson (Editors). Advances in Plant Breeding Strategies: Fruits. Volume 3. Springer, Cham., pp: 897-928.

Rivas, P., G. Mora, D. Téliz y A. Mora. 2003. Influencia de variedades y densidades de plantación de papayo (Carica papaya L.) sobre las epidemias de mancha anular. Rev. Mex. Fitopatol. 21:109-116.

Rodríguez, M., M. Alonso, Y. Tornet, L. Valero, E. Rainildes y R. Pérez. 2013. Evaluación de accesiones cubanas de papaya (Carica papaya L.) ante la mancha anular. Summa Phytopathol. 39(1):24-27.

Silva, C., A. Nascimento, J. Ferreira, O. Schmildt, R. Garcia Malikouski, R. Alexandre, G. Ferreguetti y E. Schmildt. 2017. Genetic diversity among papaya accessions. Afr. J. Agric. Res. 12(23):2041-2048.

Silva, M., S. Leonel, J. Souza, J. Modesto, R. Ferreira y A. Bolfarini. 2018. Evaluation of papaya genotypes using agronomic descriptors and estimation of genetic parameters. Biosci. J., Uberlândia, 34(4):943-951.

Storey, W. 1978. Informe sobre el cultivo de la lechosa en Venezuela y recomendaciones para un programa de producción de semilla. FUDECO. Barquisimeto. 28 p. 